\title{
Histological Effect of Female Sex Hormone to Uterine Mucous Membrane of Rat
}

By

\section{Nobuyuki IIJIMA}

\author{
Department of Histology, Tokyo Jikeikai School of Medicine (Directed by Prof. Fujio Yoshimura)
}

Fifty-two adult female rats of Wistar strain were used for this investigation. Animals were devided into such experimental groups as control, castrated, estrogen injection, progesterone administration, constant oestrus and constant dioestrus. Cytological observations were made on the mucous membrane of uterus, with special remarks of the endometrial epithelium and uterine gland. Estrogen administration (estradiol benz. $0.05 \mathrm{mg}$., estrone 8 gamma per day for 10, 40 days) increased the organ bodyweight ratio of uterus both in intact and castrated rats, 18 times in the former and 2.6 times in the latter. Progesterone injection ( $2 \mathrm{mg}$. per day for 10 days) also increased organ body-weight ratio 2.6 times.

Ten days after the castration, the cavum uteri was reduced in size and the mucous membrane was also atrophic, in which the epithelial cells and uterine gland cells were provided with low columar or cuboidal feature coincident in their internal structure with dioestrus. Within the advancing postoperative days $(45,365$ days), atrophic changes were more profound both in the epithelial cells making the plane luminal surface and in lining cells of uterine gland among which the retention cyste was frequently recognized. In constant dioestrus, the low epithelial cells also manifested the corresponding signs to those caused by the presistent castration status.

Estrogen administration to intact or castrated rats induced the pronounced hypertrophy, hyperplasia and elongation of the epithelial cells in which were present the abundant mitochondria and huge vacuoles at the basal part followed by the deformation of nuclear membrane; a certain changes caused by the castration were completely recovered to be normal or rather of hyperfunctional condition. By the administration the epithelial cells were, in case of remaining of bilateral ovaries, the thinest and tallest, therefore they exceeded the presentations in prooestrus and oestrus, in spite of the obscure discernment for the apocrine secretion; in the castrated rats the extension in length of the epithelial cells was also preferable to an elongation seen in prooestrus, and might be conditioned on amount and period of administration of the chemicals; they consisted commonly of pale cells characterized by the occurrence of stainable granules (PAS-positive) chiefly at the supranuclear portions, sometimes associated with a few number of dark hyperchromatic cells; between cells there were occasionally observed the deformed lymphocytes; the picture showing an apocrine secretion was opened to sight since the cells often protruded their own cytoplasmic processes faintly stained with iron hematoxylin. In the constant oestrus, the epithelial cells demonstrated the similar pattern either to prooestrus and oestrus or to a castration response, although they were even lower than those in above two oestrus stages, and did not perform an apocrine secretion, as the luminal surface was plane. When progesterone was administered to the castrated rats, the effect of castration was kept in the epithelial cells whose cytological feature was consistent with metoestrus.

Concerning the changes of fat granules in the epithelial cells under various experimental conditions, it was informed that castration and constant dioestrus increase the number and size of them, while 
estrogen administration to the castrated rats induces remarkable decrease in number and progestrone cannot give an influence upon them. A decided conclusion was not able to be drawn as to the glycogen content (idntified by PAS reaction) in the epithelial cells following the estrogen and progesterone administrations. It was probable, however, that the action of progesterone to the precipitation of fat granules is superior in degree to that of estrogen.

\section{A Study for the Binding of Corticoids with Plasma Protein and its Clinical Significance \\ By}

\section{Nozomu TAKEUGHI}

The 3rd department of Internal Medicine, Osaka Univ. (Director : Prof. Dr. I. Donomae)

The binding of corticoids with plasma protein was studied with the methods of dialysis equilibrium, paper electrophoresis, ultraviolet absorption and deproteinization, and the significance of its binding was discussed from the clinical view point.

The results obtained are as follows :

1) Plasma free 17-hydroxycorticosteroids bind almost with plasma protein, chiefly $\alpha$-globulin and albumin, physiologically. But cojugated 17-hydroxycorticosteroids bind at the lower rate. At the high concentration of corticoids in plasma after the administration of cortisol in vivo or in vitro, the binding ratio decreased remarkably.

2) The protein binding of corticoids is very loose and easily affected by alterations of medium $\mathrm{pH}$, corticoid concentration and presence of organic solvents.

3) The corticoids dissociated from the binding with protein have the biological activity.

4) Protein bound corticoids seem to be protected form the degradation in the liver.

5) It may be expained by the protein binding of corticoids that the renal clearance rate of free corticoids is very low.

6) The binding state is considered as "corticoid pool" which keep off the degradation of corticoids in the liver and the excretion from the kidney.

\section{Studies on Insulin Antibody}

By

\section{Masaharu HORINO, Yukimasa HIRATA, Takeshi SATO, Mitsuo ITO, Hidetaka SHIROUZU and Norimasa MAKINO}

Second Deparment of Internal Medicine (Director : Professor Shibanosuke Katsuki),

Faculty of Medicine, Kyushu University

The insulin antibody produced in guinea pigs by injecting insulin with Freund adjuvant apparantly has no effect on the endogenous insulin of the guinea pig. However, when the plasma containing

Vol. 35 No. 4 


\title{
女性ホルモンのラツト子宮粘膜に及ぼす組織学的影響
}

\author{
東京慈恵会医科大学組織学教室（主任 吉村不二夫教授）
}

飯島 信 之

\begin{abstract}
緒言
1923年 Allen \& Doisy ${ }^{1)}$ により卵胞ホルモン物質が，更に1929年 Corner \& Allen ${ }^{2)}$ にり黄体ホルモン物 質がそれぞれ発見されて以来，女性ホルモンの化学。生物学的検定等長足の進歩がもたらされた。私引は先 にラット子宮粘膜の周期性変化を細胞学的に観察した。ラットでは発情期についで排卵之黄体形成之がおて るが，生じた黄体からホルモンを分泌しているとは潘えられていない，云うまでもなく発情周期を推進する 原動力は estrogen であり。progesterone は多んどそれに参与していないと拷えられている。私は前の研究 $(1958)^{3)}$ で子宮重量，子宮内容液，子宮腺，粘膜固有首及び粘膜下組織の反応態度，更に上皮細胞の変化等， 何れあ臸スミア・テストによる周期性変化上灭衡するものであると報告した。特に上皮期，上角期には上の 諸変化における peak がある事から，ての期が発情極期であり，恐らく多量の estrogen が分泌された結果 に基づくものであらうと想像した。一方外因性に女性ホルモンを投与した場合の子宮の変化に就いては古く より多くの研究報告があつて枚挙に邀がない，何れもモルモット，ラット，ウサギ，マウス，サル等を材料 としているが，その投与量及び実験期間が相異する為か，子宮の形態的変化，特に子宮粘膜上皮細胞の変化 には一定の結論が得られていない，そこで今回，幼若，成熟ラットを使用し諸種の実験を行い，外因性或は 内因性に女性ホルモンを過剩に作用させた場合に生ずる子宮粘膜の変化，特に子宮粘膜上皮細胞の微細構造 の変化を中心に，正常発情周期による組織像と如何に相異する異常像が招来されるか，更に内因性 estrogen に基づくと考えられる上皮期，上角期の形態変化と比较して如何なる差異があるかを，詳しく検討した結果 を報告する。
\end{abstract}

\section{実験材料及び方法}

実験動物としては当教室で自家繁殖せしめた幼若及び成熟 Wistar 系雌性処女ラット（体重 120２50g） 約52頭を使用した。成熟ラットはあらかじめ腟脂宣により毎日性周期を調べ，略々規則正しい周期を営むも

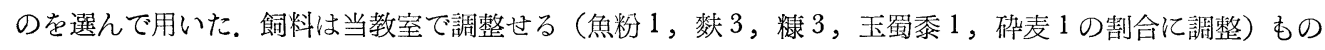
を使用し，自由飲水にまかせて供水した，室温はほぼ $22^{\circ} \mathrm{C}$ 亿保つた，実験に先立つて疾病の無い事を確め， 成長による体重の上昇が直線的グラフを示すラットを選び，それ等を下記の 9 群の実験に供した.

第 1 群 （去勢後10日）：5頭を性周期各期に随時去勢し，10日後断頭致死せしぬた。断頭時の体重は 120 〜180gであり術前と有意の変化をみない.

第 2 群 （去勢後45日）：5頭を第 1 群と同様に去勢し，45日後に断頭致死せしもた尚断頭時の体重は 130 〜160gであつた.

第3 群（去勢後365日）：6頭を同様に去勢し，365日後に断頭致死せしめた。问断頭時の体重は205～250 gであつた.

第 4 群：未処置成熟ラット5 頭に每日 estradiol benz. $0.05 \mathrm{mg}$ を10日間毎日皮下注射し，24時間後に断頭 致死せしめた。断頭時の体重は160〜250gであつた.

第 5 群 : 去勢した成熟ラット 5 頭の背部皮下に毎日 $8 \gamma$, estrone を10日間注射し，最終注射後，約 24 時間 後に断頭致死せしめた。断頭時の体重は130〜190gであつた。

第 6 群 : 去勢ラット 5 頭を用い，術後 6 日目より estrone $8 r$ を40日間背部皮下に注射し，最終注射後 24 時間にして断頭致死せしめた. 断頭時つ体重は140〜160gであつた. 
第 7 群 : 去勢ラット 5 頭を用い，2mg progesterone を背部皮下に10日間連日注射し，注射終了後24時間 後に断頭致死せしめた。断頭時の体重は140〜180gであつた。

第 8 群 (連続発情群)：生後間むない幼若ラット 8 頭に 8 r の estrone t 5 日間皮下注射し，そのまま 115日経過させた。乙れ等の動物をス之ア検查にて，10日間以上連続的に発情期を現わしたるあのを選び， 之を連続発情動物之認定し断頭致死せしめた。断頭時の体重は140〜190gであつた.

第 9 群（連続非発情群）：生後間むない幼若ラット 8 頭に $50 \mu \mathrm{g}$ estrone を10日間皮下注射後，更に $100 \mu \mathrm{g}$ estrone を10日間皮下注射し，その後引きつづいて $150 \mu \mathrm{g}$ estrone を10日間皮下注射し，90日そのままの状 態に放置せしめた。スミア検查にて10日間以上に亘り連発的に間期像を示した動物を連続非発情動物と認定 し，之を断頭致死せしめた。断頭時の体重は120〜240gであつた。

剔出した子宮は重量測定後, 速かに Levi 氏液に固定し, 型の如く paraffine 包埋, $3 \sim 4 \mu$ の連続切片在 作り，過沃度酸-Schiff 氏反応(PAS)を施し，後染色として Heidenhain 氏鉄-Hematoxylin 染色を行つた。 そ の他 azan 染色，Kull 氏染色を施したが，PAS-鉄へマトキシリン染色標本において目的にかなつた観察が 容易であつた. 尚上皮下の glycogen の証明には専ら PAS 反応によつて行つたが湮液消化試験によつて他の 陽性物質と鑑別した。.とてで女性ホルモンの投与量と投与期間について一言しておく. Inhoffen \& Hohlweg ${ }^{4)}$ (1953) は去勢ラットに対する女性ホルモンの最少有効量について, 皮下注射で a-estradiol は $0.1 \gamma$, estrone

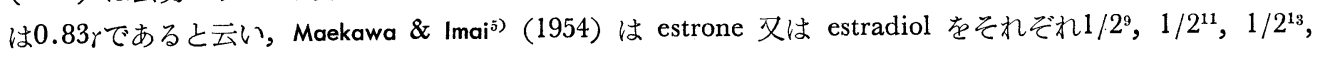
$1 / 2^{15} \mathrm{mg}$ を去勢後 5 日目より 40 日間連続注射した。そ方結果 $1 / 2^{9} ， 1 / 2^{11} \mathrm{mg}$ は臸脂育に連続的な発情状態を ひきおてし，又子宮にそれぞれの量に応じた刺战効果を誘致したが， estrone の $1 / 2^{13}$ 及び $1 / 2^{15} \mathrm{mg}$ は塍上 皮を角筫化し得ず且つ子宮に対しても無注射対照のそれとの間に差を生ぜしめなかつたと云つており，更に Greep $^{6)}$ (1950) は正常崔に estradiol benz. を注射した場合, 1 日 1R.U. (=0.166 $\left.\mu \mathrm{g}\right)$ の注射量か境界 量で，乙れ以下では卵巣に影響がないが，それ以上では卵巣の発育は逆に抑えられたと云い，又正常雌に progesterone 1 日 $1 \mathrm{mg}$ を45日間注射した結果, 生殖系続にも又下垂体前葉の卵巣刺㦸能力にも無注射対照 に比して見るべき差違を生じなかつたと云つている. 又子宮粘莫に一定の形態学を生ずべきホルモンの投与 期間として 10日，40日 では下垂体前葉の生殖腺刺战ホルモン分泌機能に影響を允分に与える事が出来る (Greep \& Hellbaumi) (1943)). 私の用いた投与量と日数とは以上の諸報告を参考にして採用したのであるが， estrone の $8 \%$, progesterone の $2 \mathrm{mg}$ 投与量は共に生理量をやや上廻るあのであり, 又 estradiol benz. $0.05 \mathrm{mg}$ はヒトでその効果程度がはつきりしている量から換算して定めたあのである. 尚連続発情群，連続 非発情群を作る投与量と投与期間は竹脇 ${ }^{8}$ (1952) の記載に従つた。

\section{実 験 成 績}

\section{I）重量変化}

図 I は各実験群に対して子宮重量を体重 $100 \mathrm{~g}$ 当りの重量平均值で現わしたるあのであるが，去勢群に於い

第 I図子宮重量の変化 $\mathrm{mg}$ (体重 $100 \mathrm{~g}$ 当りの重量平均值)

\begin{tabular}{|c|c|c|c|c|c|}
\hline 実験群 & 実 & 条 & $\begin{array}{c}\begin{array}{c}\text { 子宮重量 } \\
\text { (mg) }\end{array} \\
\end{array}$ & $\begin{array}{c}\text { ラット体重 } \\
(\mathrm{g})\end{array}$ & 例 数 \\
\hline 1 & \multicolumn{2}{|c|}{ 去勢後10日 } & 45.9 & $120 \sim 180$ & 5 \\
\hline 2 & \multicolumn{2}{|c|}{ 去勢後45日 } & 30.4 & $130 \sim 160$ & 5 \\
\hline 3 & \multicolumn{2}{|c|}{ 去勢後365日 } & 36.8 & $205 \sim 250$ & 6 \\
\hline 4 & \multicolumn{2}{|c|}{ 無倠成熟ラット+ estradiol benz. $0.05 \mathrm{mg} \times 10$ 日 } & 679.9 & $160 \sim 250$ & 5 \\
\hline 5 & \multicolumn{2}{|c|}{ 去勢 + estrone $8 \gamma \times 10$ 日 } & 89.4 & $130 \sim 190$ & 5 \\
\hline 6 & \multicolumn{2}{|c|}{ 去勢+ estrone $8 \gamma 40$ 日 } & 101.1 & $140 \sim 160$ & 5 \\
\hline 7 & \multicolumn{2}{|c|}{ 去勢 + progesterone $2 \mathrm{mg} \times 10$ 日 } & 108.9 & $140 \sim 180$ & 5 \\
\hline 8 & \multicolumn{2}{|c|}{ 連続発情 } & 134.1 & $140 \sim 190$ & 8 \\
\hline 9 & \multicolumn{2}{|c|}{ 連続非発情 } & 23.6 & $120 \sim 240$ & 8 \\
\hline
\end{tabular}


ては日数の経過に逆行する子宮重量の著明なる減少が見られず。去勢 3 群の間に推計学的に有意の差がみら れなかつた，又去勢群に比し，去勢後 estrone 又は progesterone を投与したる場合は子宮は約 2.6倍の重 量増加を示し，更に成熟ラットに estradiol benz. を投与したる場合は去勢群に比し実に約 18倍の重量增加 が見られた。去勢後，estrone 及び progesterone を別々に投与した場合には，両者の間に子宮重量におい て有意の差異がみられず，他方連続非登情群に於いては去勢群に比し更に子宮重量の減少が見られ，又第 4 群と第 5 群，第 7 群の間には推棓学的に有意の养が見られた。

\section{II) 子宮粘膜, 子宮腺の一般組織学的変化}

第 1 群（去勢10日）では子宮内腔は狭く，内腔面の山殆んどなく平坦である（図A）。粘膜の厚さは漍 少し，粘膜固有首内に於ける子宮腺の発育は不良で，散発的に僅加に出現している，腺腔む狭少となり，

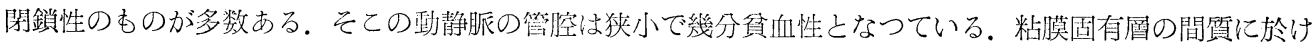
る線維細胞は豊富に存在するが，形は小さく多少萎縮性である。遊離細胞は殆んど存在しない，第 2 群（去 勢45日）では子宮内腔は更に狭小となり，内腔面の凹凸はなく完全に平坦である（図 $\mathrm{G}$ )。粘膜は一般に薄 くなり。固有屏の所見あ去勢10日群と大同小異である．第3 群（去勢365日）ではこの傾向が甚だしく,去勢 日数の延長之共に子宮の萎縮像は増覀する様である。ただ子宮腺の腺体では腺腔が部分的に拡大し，腔内に は粘膜物貿乃至 colloid の㵔留しているものがある。これは分必座物が放出出来ないために一種の retention を起したのではないかと考えられる（図E）.

次に estrogen 正常ラット（成熟）に投与した場合（第 4 群）には，子宮内腔は強く拡大し，内腔縁の彎 曲強く，凹凸著明である (図G)，粘膜は厚くなり，子宮腺の発育良好となり，分布密度が大となり粘膜の 全層に出現する，腺管は太く，恐らく延長しているらしい，蛇行しているすのと想像される，腺はそのまま 上方に達して腺上皮は粘膜上皮細胞に移行し，広い陥山部を形成している。粘膜に於ける血管の発育も良好 で充血像を示し，毛細血管の新生屯宗て著明と思われる。粘漠固有首内の線維細胞は肥大性であり，配列は 一般に緻密であるが，又ある部分では踈なる場合あある．次に去勢後 estrogen を投与して，去勢による萎 縮像の回復過程を見るに，第 $\mathbf{5}$ 群（去勢 + estrone 10日），第 6 群（去勢 + estrone 40日）では，子宮内腔は 去勢群よりずつと拡大し，内腔面の凹凸，粘膜の厚さ等何れも去勢群比して明らかに有意の回復を示してい る (図 J. M). 又子宮腺，血管の分布と発育屯よく，子宮腺腺体は直腺状，蛇行状使なり延長し，腺腔む かなり拡大している，固有層内の結合組織細胞は萎縮に陌つたあのは余りなく部分的に肥大せるあのもある が，時に軽度の水腫様变化がある，自由細胞も增加し，白血球，リンパ球も増加している，しかも，乙れ等 の変化は第 6 群に於いて一層強く観察する事が出来た。次に去勢後 progesterone 投与した第 7 群（去勢十 progesterone）では，子宮内腔依然として狭小であり，内膜面の山凸は余りなく平坦である（図 $\mathrm{P}$ ). 粘膜 の厚さむやはり娍少している。要するに progesterone 投与では去勢による影響を estrogen の様には回復 せしわない，子宮腺の発達状態からあこの事は明らかで，腺体の迂曲むなく短縮している，腺腔む狭小で閉

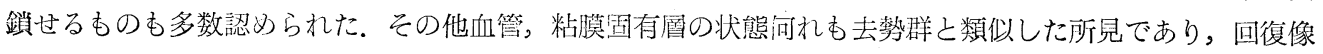
を示していない，第8群（連続発情群）では正常ラットに estrogen を投与した場合の様に著明ではないに しても，子宮腔やや広くなり，队腔面の彎兆乃至山山も怪度現われ，粘膜の厚さもかなり增していることは

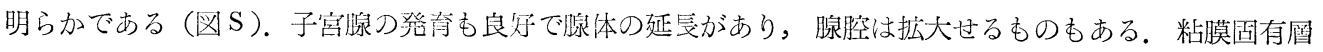
には毛細血管が多数見られ充血像を呈している，又固有首内絬合組織細胞は肥大するものが多く，配列の疎 である部分には自由細泡，リンパ承，白血球の浸潤が著明である，一方第 9 群（連続非発情群）では連続発 情群之は逆であり，子宮内腔狭く。内腔面む平滑である (図W). 粘膜は䔦く，子宮腺の発育，固有層内結

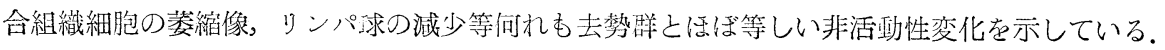

\section{III) 子宮粘漠上皮細胞及び腺細胞の細胞学的变化}

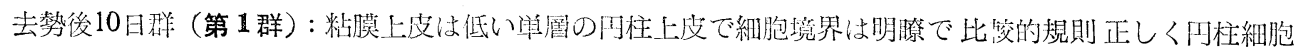
から成つている(図 B )。細胞上極部は多んど平坦で，crusta と呼べる原形質の緻密部がある。核は円形又は 棈円形で既ね細胞の中央に位し。核膜は明瞭。核内には 1 2 コの㤥小体が存在する。原形貿は大体に於い 
て明調であり，主に核上部より細胞遊離側に亘り鉄へマトキシリンに染まる徵細な可染顆粒とPAS 陽性の 顆粒之が僅かに出現するほか, 短桿状の糸粒体も少数細胞基底部より核周囲にかけて縱走するのが見られた。 これに対し，細胞基底部には，稀れには核上部にも osmium 酸に反応する徵細な脂肪顆粒が多数出現し て居り，又時に之に混じて粗大な脂肪顆粒む見られる（図 B). 細胞基底部には P A S 陽性の不定形原形質 性部分即ちグリコーゲンの出現を見る事が出来る. 以上の細胞の形態と内部構造に関する所見は腺細胞に於 いても同様であつた。

去勢後の日数が加わるにつれて（第 2 群），上皮細胞は次第に低くなり，立方形を呈して菱縮性となるが， それ程暗調ではない（図D)。しかし細胞の境界は明瞭で配列はそんなに乱れていない. 核の濃縮, 変形等は 未だ現われててない，胞体内に見られた徵細可染頖粒は第 1 群に比してやや増加するが，場所によつては明 かに著しく増加している上皮細胞があつて，細胞基底部に多数密集することがある. 糸粒体の配列状態は第 1 群之同様であるが脂肪顆粒は反つて核上部では減少するが，基底部では多数出現し，又小さい脂肪顆粒の 集積によつて生じたと思われる粗大な脂肪顆䊀が増加している傾向がみられる。グリコーゲンは第 1 群と同 様僅かばかり，主に細胞基底部にみられる，之等の上皮細胞の変化は大体に於いて発情周期に於ける間期の 知見（飯島，1958）亿相当している様に思う。

去勢後 1 年を経過した（第 3 群）ものでは，粘膜上皮は極めて低く扁平或は立方状である（図 $E ， F$ ). それであ細胞間の境界は比较的明膫である。 その際核膜に凹凸があるととと太くなつているのが目立つてい る. この時上皮の基礎膜の凹凸が見られ，そてではやや厚くなつている，原形質の萎縮性変化が高度である に拘らず，胞体法必ずしも暗調ではない，暗調な細胞では染色性が恵く，胞体が一様に染り，内部構造がわ かりにくくなる，徵細な可染顆粒は最早細胞基底部，核上部に極く僅か見られるに過ぎなく，糸粒体の存在 は不明瞭である.中には粗大な脂肪顆粒を多数含む細胞が現われる. 鬼角徵細な脂肪顆粒が減少している事 は有意の変化であらう．グリコーゲンは細胞基底部に僅か存在するがその量は極めて少くなつていることも 興味がある，以上の上皮細胞にけ於る知見は子宮腺の腺細胞にああてはまるあのであるが，但し上述の腺腔 が拡大している様な retention の時汇腺細胞全く扁平となり，原形質も乏しく，核も圧平され，原形質は 暗調で無構造に近く濃染し，その中に僅かの可染顆粒を含有するのが視い知る事が出来るに止る。

一方成熟ラットに estrogen を注射した場合（第4 群）では，粘膜上皮細胞は極めて高い円柱状で，明瞭な る細胞境界をすつて規則正しく配列する（図 $G ， H$ ). 然し細胞の遊離縁は腔内に膨隆するようなととはな く, やはり crusta 様部分をもつて腔に接している，核は長楕円形，棈円形，卵円形で長軸を細胞長軸と平 行させているが，出現位置は基奃膜に近づいた部分である，しかむ核膜には凹凸があつて変形がある。原形 質は一般に明調であるが，それ等の細胞に介在した暗調細胞が時に出現する（図 $G$ ). その細胞は染色性は 悪く, 做漫性に染まつて内部構造の判定が困難である. 明調細胞 (図H) は原形質の肥大に拘らず可染顆粒 の出現は悪く，僅かに核上方に散見するに過ぎないが糸粒体は割合に豊富に存在する，又核上部に大小の空 胞樣構造が見られる事あ特徵であるが，果して分泌空胞であるかは凝問である．脂肪顆粒はこの群では殆ん ど証明されなく,グリコーグンは細胞上極部に僅少認められるに過ざない. 要するに正常ラットを estrogen を連続投与すれば，増殖面では上皮細胞の肥大となつて現われるが，細胞の機能を積極化する様な影響を確 実に与えるか否加，現在の組織学的所見からは一寸判断しかねる. 次に粘膜固有首に於ける子宮腺の腺細 胞であるが，その形態及び内部構造は粘膜上皮細胞のそれと大同小異である（図 I ）。但し胞体の遠位部之 思われる場所では，細胞はそんなに高くはなく，胞体内には此较的多くの可染顆粒又は PAS 陽性顆粒を認 める事が出来たが，旺盛なる分泌現象が招来されているとは思えない様な所見であつた。

以上は成熟無傷動物に estrogen を投与した場合に於ける所見であるが，次に成熟動物を去勢した後に estrogen を投与した場合の変化について述べる. 変化はほぼ同じであつたが以下述べる点に於いて若干の相 違がある。即ち第 5 群（去勢+ estrone 10日）では粘膜上皮細胞は狭小な高い円柱状を呈し，子宮腔内に原 形質の一部がしばしば膨隆していることが異なる。 又其の内部構造に於いては徵細な可染顆位が前とは異な り殕富に存在し，又特に核上部に集合する傾向がある (図K. L). その他大きい不定形の空胞が所々に出現 
し，或いは細胞基底部に集矮带を形成して，下より核を圧迫して変形を起させる場合がある。核膜に山凸を 生ぜしめる事も㞗々である。一方糸粒体もよく保持固定され核上部には顆粒状の糸粒体が多数認められる。 基奃部大空胞の内には大小様々の顆粒之共に不定形の PAS に強く厚応するゲリコーゲン物質が封じ込まれ

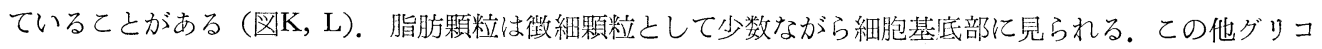
一ゲンが核上部に僅か乍ら見る事が出来た. 要するに estrogen は粘膜上皮細胞に対して肥大化作用を持つ のみならず，代謝面でも細胞の内部構造に或る 程度 の機能充進像と判断させる諸変化を現出せしめる事が 出来た．乙の変化は子宮腺の腺細胞であやはり同じであるが，第 4 群がそうであつた如く，特に胿盛なる apocrine 分泌等は認められない，唯々核上部に PAS 陽性の顆粒が密集しているだけである。前に見られた 如き腺腔に分泌産物が渚留している像は認倳が出来なかつた。.以上の所見を正常ラット発情周期の上皮 期と上角期に比较すれば゙親近性か確認された。両者では明らかに上皮細胞は高く，而屯幅が狭小であり，增 殖性変化は高度であるが，上皮の自由縁は estrogen 投与によつて上皮期，上角期に優る強い apocrine 分 泌がおこつているとは思われない，大体同じ程度のものではないかと思考される．次に第 6 群（去勢十

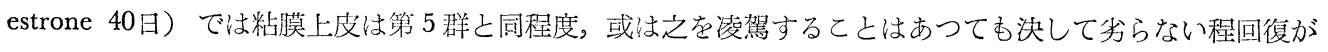
よく。やはり狭小なる円柱細胞加ら成つている (図 $\mathrm{M}, \mathrm{N}$ ). 細胞の自由縁に於ける原形質の膨隆部は一㬝高 度であり，明らかに前よりも apocrine 分泌は積極化している様にも思われる．又との群では上皮細胞間に 白血球が遊走している像(図N)を認邓る。遊走白血球の核は長棈円形或は楕円形で，核内に $1 \sim 2$ コの核小 体を有している。遊走白血球の出現場所は上皮の中央部或は基奃部に寄つた所であり，その出現頻度す第 5 群に比しかなり大きくなつている，粘膜上皮細胞の原形質は一般に遊離側近くは暗調であるが，他の部分は 大体明調である，徵細な可染顆粒は細胞全域に分布するが，第 5 群に比しやや增加する傾向があり，特に核 上部と遊離側に集合する事が多く，その時顆粒の直径むやや大きくなつている，糸粒体は細胞基底部では短 桿状であるが, 細胞の遊離側に至るにつれて顆粒状となり，自由縁の下ではてのあのが密集して暗調を呈 し，Crusta に接着している．やはり大小の顆粒や，不定形のグリコーゲン物質を含有する大空胞を少数な がら備えているが，かかる空胞の出現頻度は第 5 群に比して劣つている。，穴他脂肪顆粒及びグリコーゲン の細胞内分布の状態は第 5 群とほぼ同様である，子宮腺の細胞はこてであ粘膜上皮細胞に比べると低く，幅 も厚くなつているが，内部構造も大体同じであり，やはり apocrine 分泌像も屢々見られ，核上部に PAS 強陽性顆粒の集積があつた，この場合には，腺腔内に分泌物が渚留しているような所見ではない．斯の如く 去勢によつて生じた粘膜上皮細胞の変化は estrogen の投与により回復するのみならず，之を上廷り反つて 增殖と分泌機能つ亢進とがおこる様であつた。然るに去勢後 progesterone を注射すると（第 7 群），粘膜上 皮の高さは回復せずやはり丈が高くなく，細胞は円柱状であるが，細胞間の境界はやや不明膫であり，細胞 配列む余り整然としていない（図Q，R）。自由縁は平坦であり，第 6 群に見られた如き分泌突起の像も出現 していない，更に上皮の基奃膜は至つて不明瞭で，出凸をつて上皮下の粘膜固有首に接している．原形質 はやや暗調で，遊離側は強く整漫性に染り，大小の可染顆粒は胞体全域に見られるも，特に核上部より遊離 侽にはかなり集合している。胞体内可染顆粒の出現量は第 6 群の estrogen 投与と同㥞であるが，顆粒の大

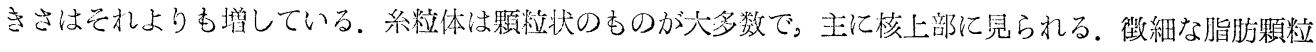
は細胞基氐部に多数出現する任か核上部にす少数ながら存在するのである。一方グリコーゲンは主に細胞の 核上部に見られるが，洔に細胞基氐部にやや大きい集塊として敞存するのが見られ，グリコーグンの出現量 は estrogen 投与よりあやや多い様に感ぜられた。 又細胞基同部には大空胞が出現し，ての中に不定形の可

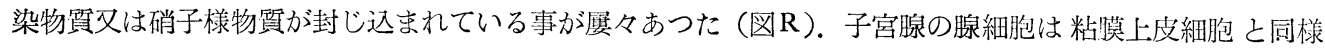
の内部構造であるが。原形質はやや明調で，可染顆粒もやや少なく。核上部に見られる PAS 強陽性顆粒も estrogen 投与群に比し少い棁である. 婹するに去勢後 progesterone を投与しても去勢の影響を抑える事が 出来ないととを知り得た。然し粗大な脂肪顆粒が消失しているととは確かであつた。形態学的には角化期の 像と似ているのである.

連続発情ラット（第 8 群)では粘漠上皮は高く。細胞の境界は朋嘹でやや配列の乱れた円柱上皮である(図 
T). しかし正常に estrogen を投与した第 4 群に比すれば高さす減じ，又規則正しい配列も遥かに少る。細 胞の自由縁にはやはり軽度の膨隆が見られ，時に apocrine 分泌性の原形質性突起像を見る事が出来た。胞 体の内部構造は第 4 群，第 5 群とほぼ同じであつて，細胞遊離侧には多くの比較的粗大な可染顆粒が限局性 に現われ（図 $\mathrm{T}$ )，系粒体む細胞全域に豊富に存在し，又所々に大空胞がある。然し 8 例中 3 例に於いては 連続発情性によつて恰も正常ラットに estrogen を投与した㭙と同じ様な極もて高い粘膜上皮となり，構成

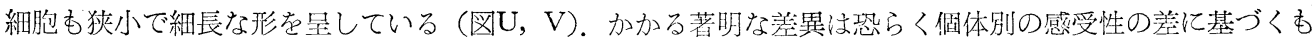
の之解釈する以外の意味づけは考光られない，以上の上皮細胞の所見は第 4，5群之大体に於いて似てお り，多数の可染顆粒之糸粒体とを弇有しており，脂肪顆粘む細胞基底部或は核上部等に分布し，時に之等が 散発的に集合して出現することがある。宫腺の腺細胞も粘膜上皮細胞之大体同様の变化が起きているが， 中に腺管が宮腔に移行寸る部分では㭙に核分裂像分淏られた。宫腺細胞の遊離緑にもやはり apocrine 分泌の突起像を見る事が出来た，apocrine 分泌によつて腔内に原形質の一部が版出されたと思われる様な 渚留の像が明らかに認められた。

最後に連続非発情（第 9 群）では粘膜上皮は極》て低くなり（図 $\mathrm{W}, \mathrm{X}$ )，円柱状乃至立方形細胞よりな

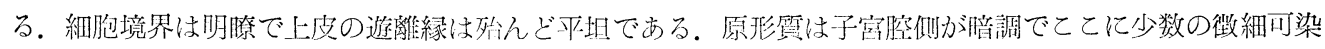

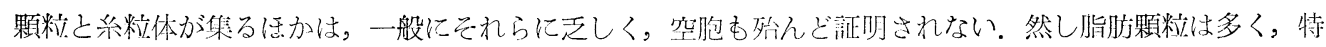

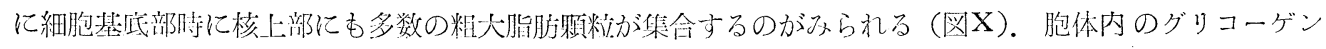

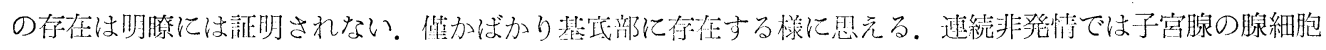

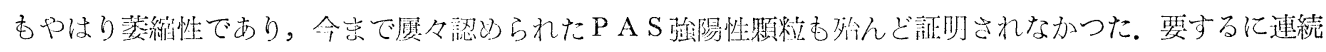

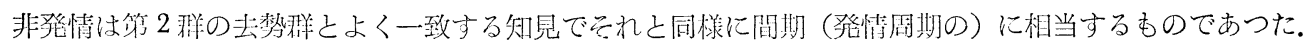

\section{考察}

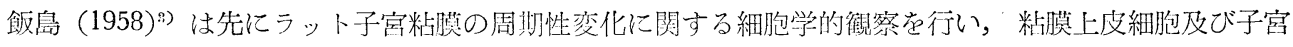

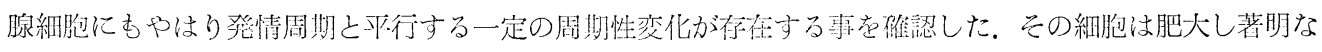

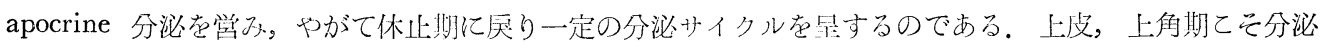
機能の頂点であり，閭期は休止期であると推定した。ラットでは上卜に見られる様な粘膜の完全な脱落は存 在しないけれども，時には粘膜上皮細胞の崩壊に伴う脱深があり，乙の欠損部を上皮深尿から新生される細

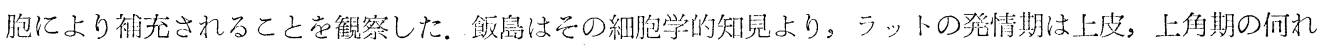
かであり，排卵は恐らく上角期より角化期の前半におこり得るあのなる事を推定した，從つて登情期に於い て最す多量の estrogen が作用する時期はやはり，上皮，上角期で，estrogen が殆んど作用しないか，極く

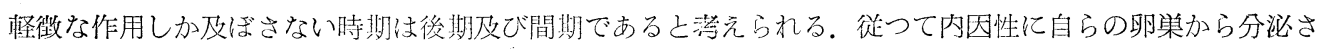
れる estrogen によつて登現する子宮粘膜上皮及び脉細抱の変化之，外因性に与光られた estrogen に反応 するこれらの態度の異同在観察する事は，子宮粘膜の根木的な液性要因を掘りさげる点で必要なととでは

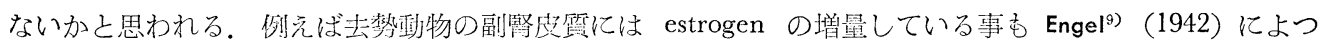
て碓ひられ，又 Ilusia9) (1953) は去勢㷌人に gonadotropin 芭投与すると androgen, progesterone が增 量しているととを報告し，第 3 性腺として副婜皮質の重要性が增している事も，生殖器のホルモン調節が 必ずしも単純ではない面を示している。 今回の去勢群の子宮重量は減少し，粘膜上皮細胞は低く萎縮性之 なり，その内部構造の变化を併せ孝えると，正常発情祘期に於ける間期に相当する様であり，去勢後の日 数の経過（45日，365日）之共にての傾向は一層進展し，粘摸上皮は極めて低くなり，粘膜の萎縮も一層

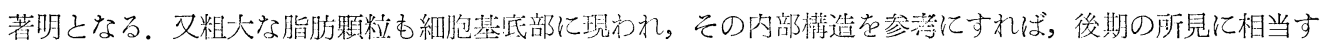

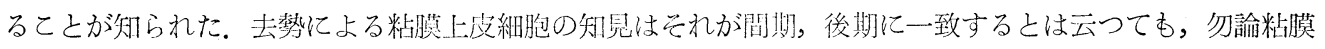
に於ける一般組織学的变化から寸れば。去勢に上る美縮性变化は間期, 後期よりあ更に高度であり, 全面的

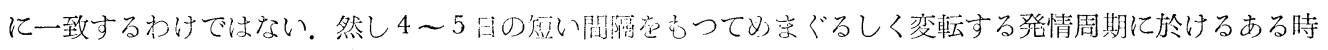

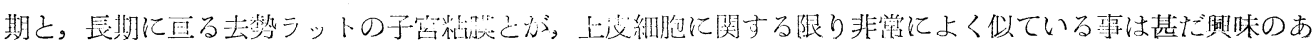


ることである。

次に去勢ラットの子宮に及ぼす estrogen，progesterone の效果をしらべてみた所，estrogen では回復を上 迴る変化，即ち粘膜全般にわたり寧ろ機能六猚を示す像が得られたが，之は投与量が多すぎた為の結果と思 われる。ささて，とてでとの課題に関する過去の業績につき言及してみる，Courrier \& Potvin ${ }^{10)}$ (1926) は去 势ウサギに卵胞液を $2.5 \mathrm{cc}$ 注射する事により子宮に充血，浮腫，或は上皮細胞の異常肥大，子宮腺の良好な 発達を報告し，Loeb \& Kountz ${ }^{11)}$ (1928) はモルモットで同様の所見を得ている. Allen ${ }^{12)}$ (1928) はサルを 使用し，oestrin の 1,000 r.u. 以上の投与により筋層，腺上皮の增殖を認め，Smith ${ }^{13)}(1932)$ は oestrin を去 勢ネズミを使用して子宮に著明な活動的反応を認如，Moricard ${ }^{14)}$ (1934) はラットの子宮が拡大するのを認

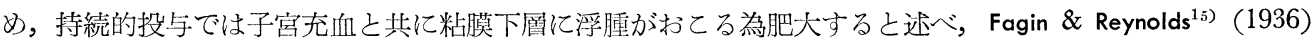
は去勢わサギに estrogen を投与すると血管拡大と浮䭪が発現するととを，Smith＆ Gardner ${ }^{16)}$ (1937) は去 勢 2 ケ月後のラットを使用して estrogen を投与した所充血と浮腫の発来を認め，又上皮，腺に於ける核分 裂を認めた。 Khayyal \& Scott ${ }^{17) 18)}(1931 ， 1935)$ は哺乳動物の新鮮な卵胞液をネズッに皮下注射すると，子 宮の酸素消費の上昇が見られると述へ，David \& Freud ${ }^{19)}$ (1934) は去勢门サギを，Lacassagne ${ }^{20)}$ (1935) は マウスを Barks \& Overholser ${ }^{21)}(1936)$ はサルを用い, estrogen を投与したところ何れむ子宮の間質は大いに 增殖した。 Werner \& Collier ${ }^{292}$ (1933) は去勢せるヒトに於いて estrone の投与により子宮の拡大と腺の発育 分枝，更に内膜の著明は発育と肥大とを認め，Brouha \& Simonnet ${ }^{23)}$ (1927) はラットを，Reynolds ${ }^{24)}$ (1931) はウサギを用い，estrogen 投与は子宮筋肉の活動，収縮を增加させる事を認め，子宮は estrogen により敏 感になると云つている，以上の如く estrogen の子宮に対する影響に言及した報告は極めて多数に昇つてい る。一方外因的に与えられた estrogen は下垂体前葉に作用して FSH の分泌を抑制するととは明らかであ るが，反面L H分泌を誘発する能力のある事が Hohlweg ${ }^{25}$ （1934），Hellbaum ${ }^{26}$ (1943) 亿よつて確認されて いる. Wolfe ${ }^{27)}$ (1931) は estrogen の投与量が小なる場合にはL H分泌は増強され，大量なる時には却つて 減退すると述べている。従つて estrogen 投与の場合と雖も，LH の分泌を介して progesterone が放出さ れるととああり得るわけであるが，非妊ラットでは黄体より progesterone が分泌される事は先づないので， この点は無視出来ると思う。去勢ラットに estrogen を投与した場合の子宮の変化を見ると，粘膜上皮は甚 だ高く細胞は狭小であり，上皮の高さは去勢群の数倍にあ及んでいる。而も細胞上極部は腔内に膨隆し，或 る程度の apocrine 分泌を営んでいる様である. estrogen が長期間投与されればての傾向は大となり，可染 顆粒が多くなつている，乙の期の細胞は正常発情周期に於ける上皮期及び上角期よりも明らかに高く，分泌 機能が旺盛である。しかし細胞の内部構造からすれば明らかに上皮，上角期の範疇に属すべきものであらう。 従つて去勢後の estrogen 投与方式によつて異なれる所見も得られるわけで，例光少量であ去勢直後より長 期間連続投与された場合には, 大量を一時的に投与するよりあ有效である。 この点は Lipschutz \& Rodriguez ${ }^{28)}$ (1941) の説を裹書きする結果となつた。

次に progesterone の子宮に対する影響であるが, Constantinides ${ }^{29)}$ (1947) は毎日0.5〜3mgの progesterone をラットに投与した場合，子宮の間質の結合組織細胞の核を大きくさせ，特に上皮細胞の直下の粘膜固有層 ではこの傾向が強く，又去勢後 $3 \mathrm{mg}$ の progesterone を 3 日間投与した場合，上皮細胞に接した間質には結 合組織細胞の核分裂が認められ，乙れ等は estrogen 投与により防止する事が出来たと指摘した。. 次に内膜, 子宮腺に対する progesterone の作用は分泌促進作用であり，estrogen の上皮細胞を増殖させる作用とは対 称的であると述べた事は注目される。凧藤へ(1927）は黄体物質を注射しても去勢ラットの性周期を回復せ しめる事ができず, progesterone には子宮粘膜, 腺上皮の発有を促す作用が梖げ骑いと云つている. Hooker ${ }^{11}$ （1945）は去勢マウスに progesterone を投与すると子宮内膜の間質細胞核に特有な胞状肥大をおこす事を認

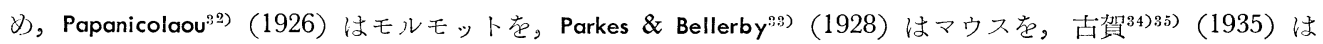
ラットを用い，progesterone を投与すると正常の発情周期を混乱導き，特に発情期登現抑制作用のある事

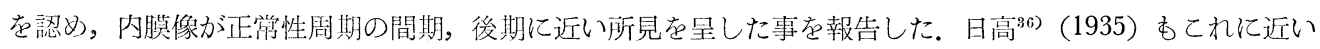
所見を観察した，然し progesterone 投与による粘膜上皮細胞の内部構造の変化について詳しく言及した人 
はいない様である，私の去勢，progesterone 投与トットの標本によれば，去勢による子宮腔の縮小，粘膜上 皮，子宮腺の不良なる発育状況，貧血，粘膜全般の萎縮等，凡ての点に亘つて回復は認わられず，粘膜上皮 細胞の形態は後期と一致したととは興味がある。しかし去勢時には間期に相当し，粗大な脂肪顆粒が細胞基 底部に密集していたが，乙ん度は後期の像であり可染顆粘が多数存在していた．又巨大空胞が多数出現する

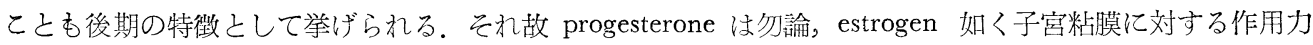
は強くはないが，それでも間期を後期様の所見に変えることは興味が持てれる．然し現在の所その意味は不 明である。一方無処置ラットに estrogen を連続投与した時に粘膜上皮は正常間期の数倍に達し，上皮，上 角期の 2 倍にも達する肥原性変化を認めた。然し a pocrine 分泌が元進している様な像ではなく，子宮腔侧

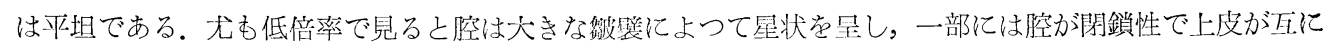
相接しているものがある。この様に非去勢うットでは增列性変化は一層顕荠であるに拘らず，代謝面ではや はりそれ程血進しているとは思えないのである。

次に連続発情及び連続非発情の所見について考察する。生後間むなく estrogen を投与して卵采機能に異

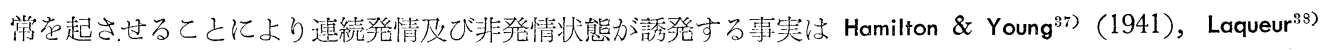

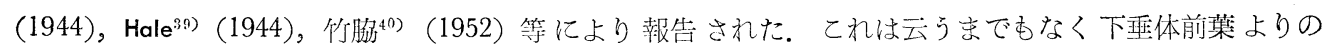
gonadotropin 放出に異常が起る事に原因がある。竹脇 ${ }^{40)}$ (1952) 飞上れば出生直後よりはじもて estrone を1/80〜1/40mg を20〜40日間注射すると，注射を受けた雌性ネブミが十分に成熟してす，乙れ等のネズミ

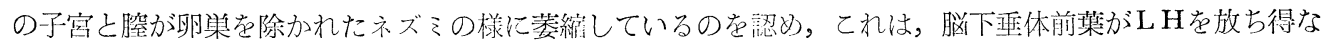

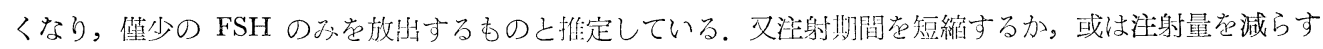

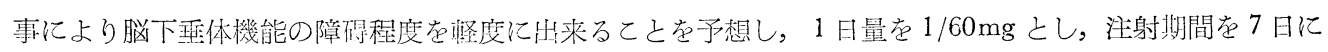
限り投与したるととろ，成熟後に於いて長期に亘つて連続的に発情をおこす事を認めた。乙れを説明して脳

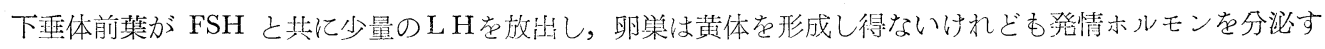
る事が可能であるとしている，今回の実験む竹脇の方法に従つて行つたのであるが，連続登情群に於いては 個体差があつて凡て一定した成續ではなかつた，子葟重量は一般に增しているが，上皮細胞の高さには高低

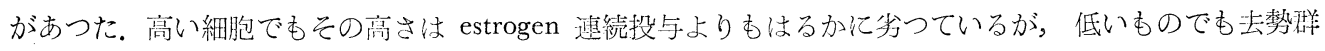
よりは遥か滈い，要守るに結果的には estrogen が絶えず粘膜に作用している様な像であつたが，発情周 期の上皮，上角期化比して細胞高，分泌像に於いても劣つていて，低い場合には角化期に相当する様な内部 榛造をむつあのであつた，次に連続非発情群では，粘膜上皮は極めて低く，子宮の菱縮像が著明であり，辰 期去勢群（365日）之同心゙様な上皮細胞の内部所見で，基底部に粗大な脂肪顆粒が見出され，正常発情周期に 於ける後期之一致する所見であつた。この場合 estrogen が顕著な影㗽を子宮に与えていないととを示す反 応であつた。

最後に粘膜上皮及び腺上皮細胞に出現する脂肪顆粒とグリコーゲンの存在意義について一言する．今回の 実験を通覽すると，脂肪顆粒には微小のあの之粗大なすのとがある，微小のあのは細胞の全域に不平等に出

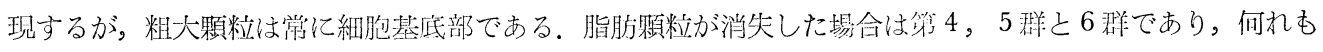
estrogen に反応して細胞が高く，或いは機能九准を起した時である。，一方粗大脂肪顆粒が泏現するのは第 1 〜3 群，9礁であり，estrogen が多々ど作用しなかつた場合にのみ出現する．要するに細胞質の内に蛋白之 シセル結合をしている脂肪粒子が，細胞の機能減退又は何等かの病的状態傺して蛋白との結合がとけ可視 的脂肪顆粒となつて現われて来るととが菱えられる（de Robertis）ので，正常周期に於ける後期ですやは

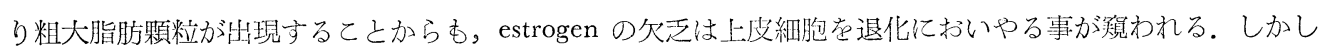
細胞内の脂肪顆粒の運命についてはわかつていない，György \& Rose ${ }^{41)}$ (1949), Engelberg92) (1955) 等は progesterone 之脂肪顆粒との関係を重視したが。生理量程度の progesterone では血清脂肪の量には見るべ 変動を示さなかつた．然るに Alden ${ }^{(3)}$ （1947）は外因性 progesterone 投与により血清脂肪の著しい增加が

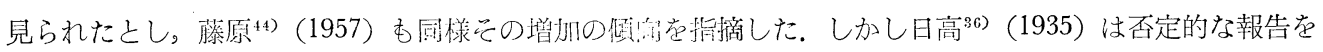

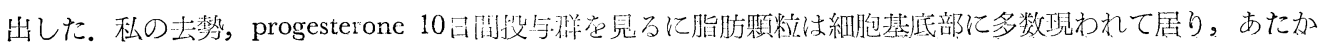


あ去勢10日後断頭群に近き所見であた。しかし progesterone 投与時にのみ脂肪顆粒が腔内に放出されず血 液内に浸入するのか否かは問題である。一方上皮及び腺細胞内のグリコーゲンの消長については Lendrum \& $\operatorname{Hisaw}^{45)}(1936)$ は estrone をむつて治療されているサルの子宮内膜細胞には殆んど認められず, progesterone を投与せる場合には核と基底膜との間に透明部を生じ，その中にグリコーゲンが濃縮された状態で保存され ると云い，Hisaw \& Greep ${ }^{46)}$ (1938) は子宮内膜細胞に於ける progesterone の作用はグリコーゲンの蓄積で

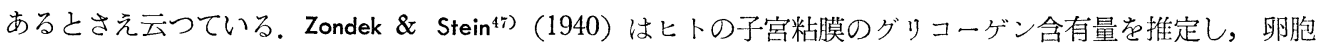
期よりあ黄体期に多い事を見出している。 Ingle ${ }^{48}$ (1944), Rodriguez \& Martinez ${ }^{49}$ (1951) は雌性ラットの卵 栄と大部分の膵を剔除すると1〜2ケ月で糖尿病をおこすが，てれに estradiol を皮下注射すると糖尿病を 柽快させるか少くとあ発病時期を遅くらせる事が出来るとし，estrogen が糖代謝にかなり強い影響を有する 事を示している，又 Atkinson ${ }^{50)}$ (1952) は去勢したラットに滤胞ホルモンを注射するとグリコーグンが增量 する事を組織学的に証明した。 今回の実験では去勢群には減少の傾向が見られ，特に去勢後の日数の增加す るにつれて減少の程度が進行するものと思われた。一方 estrogen 投与群をみるに共に細胞上極部に僅か存 在するのがみられ，時に大空胞内に存在せる場合は空胞中に不定形の集合体が見られ，progesterone 投与群 に於いては細胞の核上部に，時に細胞基底部にかなりみられたが，その量は estrogen 投与時に比しやや多 い様であつた。教室の鈴木 ${ }^{51)}(1958)$ は汗腺の腺細胞に於けるグリコーゲンと汗分泌の関係を諭じ，特に副 婜，甲状腺との関係を観察したが，機能が低下した如き細胞の形態を備える時には増え，肥大性で機能がえ 進すると思われる時には減ると云う事実を得ているが，之の事が，子宮粘膜上皮にはこのまま当てはまる にしては，余りにも変化が複雑すぎている。

総括

当教室で自家繁殖した，幼若及び成熟 Wistar 系雌性処女ラット約52頭を使用し，去勢，estrogen 投与， progesterone 投与，及び連続発情，連続非発情の実験を行い，子宮粘膜及び腺細胞の変化を中心に細胞学的 立場より子宮粘膜を観察して，下記の結果を得た。

1）無傷及び去勢ラットでは estrogen 及び progesterone は共に子宮重量を増加させる．即ち無倠ラット では約18倍, 去勢ラットでは約2.6倍の重量増加が見られた。

2）去勢群の子宮粘膜上皮細胞の変化を見るに，去勢後10日では細胞は低い円柱状で，その内部構造は間 期之類似せる所見を呈していた，去勢後の日数が長期に及ぶに従い粘膜上皮細胞の萎縮像が著明となつた。 又子宮腺細胞の変化も同様であるが，腺腔が拡大して暂留物がみられた。

3）連続非発情群の粘膜上皮細胞は大体に於いて長期去勢群に近い像を示していた.

4）無傷及び去勢ラットに estrogen を投与する之何れも子宮柡の発育肥大，更に子宮粘膜上皮細胞の著 明なる肥厚等增殖性変化が強かつたが，後者では恐らく回復を上廻つたものであつた．前者では上皮細胞は 㹨小で甚だ高く，特に上皮，上角期を凌ぐ高さに達したが旺盛なる分泌像を必ずしも発現しなかつた，後者 では大体上皮，上角期を淩〈゙所見であつた。 上皮細胞には若干の apocrine 分泌像を認めた。

5）連続発情群に於いてもやはり上皮，上角期と似た粘膜上皮細胞であつたが，それよりあ丈がやや低く 分泌像は極めて不明瞭であつた。

6）去勢ラットに progesterone を投与すると，粘膜上皮細胞にはやはり去勢の影響が残り回復しない. 後期之一致する像であつた。

7）以上の実験に於いて粘膜上皮細胞内に現われる脂肪顆粒の消長を見るに，去勢，連続非発情によつて 増加するが， estrogen 投与では明らかに消失或は著明に減少した。一方 progesterone 投与では余り影響を 及ぼさなかつた。

8) estrogen, progesterone 投与時に於けるグリコーゲンの増減については明白な結論は得られなかつた が， progesterone 投与時の方が estrogen 投与時よりも幾分増玑したようであつた。

終りに終始御㸸篤なる御指導と御校閲を睗わつた恩師吉村教授並びに実験に際し種々御指導下された前川 


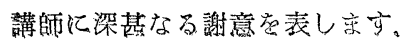

\section{参考文献}

1) Allen, E. \& E.A. Doisy : J. Am. Med. Ass., $81: 819,1923$.

2) Corner, G.W. \& W.A. Allen : Am. J. Physiol., 88 : 326, 1929.

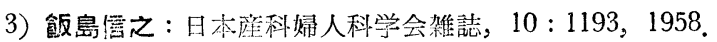

4) 藤 井吉助他：産㷌人科の世界，5:2より参照，1953。 5 5) Maekawa，K. \& K. Imai : Annotatlones Zoologlcae Japanenses Vol.27, 1, $1954 . \quad 6$ 6) Greep, R.O. \& I.C. Jones : Recent. Progrin Hormone. Res., $5: 197,1950 . \quad 7)$ Hellbaum, A.A. \& R.O. Greep : Endocrinology, $32: 33,1943 . \quad$ 8) 竹助潔 :

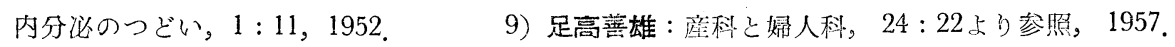

10) Courrier, R. \& R. Potvin : Compt. rend. Soc. Biol., $94: 878,1926 . \quad 11)$ Loeb, L. \& W.B. Kountz: Amer. J. Physiol., 84 : 283, 1928. 12) Allen, E. : J. Morph. Physiol., $46: 479,1928$. Sm:ih,P.E. : Amer. J. Physiol., 99 : 345, 1932. 14) Moricard, R. : Proliférine sexuelle femelle. Paris. 1934.

15) Fagin, J. \& S.R.M. Reynolds : Amer. J. Physiol., $117: 86,1936$.

16) Smith, G.M. \& W.U. Gardner : Amer. J. Anat., $61: 321,1937 . \quad 17)$ Khayyal, M.A. \& C.M. Scott : J. Physiol., $72: 13,1931 . \quad$ 18) Khayyal, M.A. \& C.M. Scott : Quart. J. exp. Physiol., $25: 77,1935$.

David, K. \& J. Freud : Biochem. J., 28 : 1360, 1934.

20) Lacassagne, A. : Compt. rend. Soc. Biol., $120: 585,1935$. 21) Barks, O.L. \& M.D. Overholser : Anat. Rec., 70 : 401, 1938.

22) Werner, A.A. \& W.D. Collier : J. Amer. med. Ass., $100: 633,1933$. 23) Brouha, L. \& H. Simonnet : Compt. rend. Soc. Biol., $96: 96,1927$.

24) Reynolds, S.R.M. : Amer. J. Physiol., 97 : 706, 1931. Hohlweg, W. : Klini. Wocheschrift., $13: 92,1934 . \quad 26)$ Hellbaum, A.A. et al. : Endocrinology., 32 : 33, $1943 . \quad 27)$ Wolfe, J.M. : Amer. J. Anat., $49: 391,1931 . \quad 28$ ) Lipschutz, A. \& F. Rodriguez : Endocrinology, $28: 664,1941 . \quad 29)$ Contantinides, P. : J. Endocrinol. 5. Proc. Lxiv. $1947 . \quad 30)$ 斉藤公平 : 実験医学雑誌, $11: 1571,1927 . \quad 31)$ Hooker, C.W. : Anat. Rec., $93: 333,1945 . \quad 32)$ Papanicolaou, G.N. : J. Amer. med. Assc. 86, $1926 . \quad 33)$ Parkes, A.S. \& C.W. Bellerby : Amer. J. Physiol. Vol. 64，1928. 34) 古賀康八郎：日本婦人科学会雑誌，31:1956，1935. 35) 古賀康

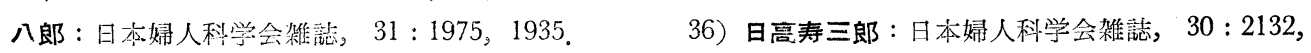
1935. 37) Hamition, J.B. \& W.C. Young: Endocrinology, $29: 779,1941 . \quad 38$ ) Laqueur, G.L. : Proc. Soc. Exp. Biol. and. Med., $55: 269,1914 . \quad 39)$ Hale, H.B. : Endocrinology, $35: 499,1944$. 40）竹助潔：内分必のつどい，2:387，1952. 41) Gyögy, P. \& C.S. Rose : Arch. Biochem., 22 : 108, 1949. 42) Engelberg, H. \& S.J. Glass : Metapolism, $4: 298,1955 . \quad$ 43) Alden, B. : Anat. Rec., $97: 1,1947.44)$ 藤原郎：日本産科㷌人科学会䧱誌，9:261，1957. 45$)$ Lendrum, F.C. \& F.L. Hisaw : Proc. Soc. exp. Biol. \& Med., $34: 364,1936 . \quad$ 46) Hisaw, F.L. \& R.O. Greep : Endocrinology, $23: 1,1938 . \quad 47)$ Zondex, B. \& L. Stein : Endocrinology, $27: 395,1940 . \quad 48)$ Ingle, D.J. : Endocrinology, $34: 361,1944 . \quad 49)$ Radriguez, R.R. \& C. Martinez : Compt. rend. Soc. Biol., $145: 125,1951 . \quad 50)$ Aikinson, W.B. et al. : Anat. rec., $113: 101,1952 . \quad 51)$ 鈴木哲五郎 : 符1148回成医会口演，1958.

\section{写 真 説 明}
A. 去勢後10日のラット子宮 Levi 氏液固定，PAS-鉄へマトキシリン染色 $(10 \times 10)$
B. 去奜後10日のラツト子宮粘膜上皮細胞 Levi 氏液圆定，PAS一鉄へマトキシリン染色 $(10 \times 90)$ 細胞内に 微細な脂肪顆粒が見られる
C. 去勢後45日のラット子葟 Levi 氏液固定，PAS-鉄ヘマトキシリン染出 $(10 \times 10)$
D. 去梦後 45 日のラツト子富粘膜上皮細胞 Levi 氏液国定, PAS一鉄へマトキシリン染色 $(10 \times 90)$ 細胞基底 
部に粗大な脂肪顆粒がみられる。

E. 去勢後365日のラット子宮 Levi 氏液固定, PAS-鉄へマキシリン染色 $(10 \times 10)$ 子宮腺に cyste がみら れる。

F. 去勢後365日のラツト子宮粘膜上皮細胞 Levi 氏液固定，PAS-鉄ヘマトキシリン染色 $(10 \times 90)$ 粘膜上 皮細胞は低く，脂肪顆粒は極めて粗大である。

G. estradiol benz. 0.05mg，10日間注射せる成熟ラットの子宮 Levi 氏液固定，PAS一鉄ヘマトキシリン染色 $(10 \times 10)$

H. estradiol benz. 0.05mg，10日間注射せる成熟ラットの子宮粘膜上皮細胞 Levi 氏液固定，PAS-鉄へマト キシリン染色 $(10 \times 90)$ 上皮細胞極めて高く，mitochondria が豊富である。空胞により核は压迫され 変形している.

I. estradiol. benz. 0.05mg, 10日間注射せる無傷成熟ラットの子宮腺 Levi 氏液固定，PAS-鉄へマトキシリ ン染色 $(10 \times 90)$ 細胞の核上部に PAS 強陽性の顆粒が多少みられる。

J. 去勢後 estrone $8 r$ を10日間注射せるラツト子宮 Levi 氏液固定，PAS-鉄へマトキシリン染色 $(10 \times 10)$ 上皮は高く去勢の影響は回復している。

K. 去勢後 estrone 8r を10日間注射せるラット子宮粘膜上皮細胞 Levi 氏液固定，PAS一鉄へマトキシリン 染色 $(10 \times 90)$ 上皮細胞芯狭く高い，その間に暗調細胞が介在する。.

L. 去勢後 estrone $8 r$ 党10日間注射せるラツト子宮粘膜上皮細胞 Levi 氏液固定，PAS-鉄へマトキシリン 染色 $(10 \times 90)$ 高い上皮細胞内に遊走細胞（个）が見られる.

M. 去勢後 estrone $8 r$ を40日間注射せるラット子宮 Levi 氏液固定, PAS-鉄ヘマトキシリン染色 $(10 \times 10)$ 10 日間と同様上皮は高い.

N. 去勢後 estrone $8 r$ 党40日間注射せるラット子宮粘膜上皮細胞 Levi 氏液固定，PAS-鉄ヘマトキシリン 染色 $(10 \times 90)$ 細胞上極部膨隆し apocrine 分泌を暗示する。胞体内に可染顆粒見られる又遊走細胞あり.

○. 去勢後 estrone $8 \gamma$ 存40日間注射せるラツト子宮腺細胞 Levi 氏液固定，PAS-鉄ヘマキシリン染色（10 $\times 90 ）$ 細胞の尖端に原形質性分泌突起あり，核上部に PAS 強陽性の顆粒增加している.

P. 去勢後 progesterone $2 \mathrm{mg}, 10$ 日間注射せるラツト子宮 Levi 氏液固定，PAS-鉄ヘマトキシリン染色 (10 ×10）去勢の影響は消失しない.

Q. 去勢後 progesterone $2 \mathrm{mg}, 10$ 日間注射せるラツト子宮粘膜上皮細胞 Levi 氏液固定，PAS-鉄へマトキ シリン染色 $(10 \times 90)$ 小さい脂肪顆粒が豊富に存在する.

R. 去勢後 progesterone $2 \mathrm{mg}, 10$ 日間注射せるラツト子宮粘膜上皮細胞 Levi 氏液固定，PAS一鉄へマトキシ リン染色 $(10 \times 90)$ やや淡く染色された可染顆粒と osmium を還元した脂肪顆粒が見られる。

S. 連続発情せるラット子宮Levi 氏液固定，PAS-鉄ヘマトキシリン染色 $(10 \times 10)$ 上皮は高いが， estrogen 投与群に及ばない。

T。連続発情せるラット子宮粘膜上皮細胞 Levi 氏液固定，PAS-鉄へマトキシリン染色 $(10 \times 90)$ 上皮細胞 内にかなりの脂肪顆粒見られる。

U．連続発情せるラット子宮粘膜上皮細胞 Levi 氏液固定，PAS-鉄へマトキシリン染色 $(10 \times 90)$ との例で は上皮は甚だ高い，上皮細胞内に脂肪顆粒。遊走細胞が見られる。

V. 連続発情せるラツト子宮粘膜上皮細胞及び子宮腺開口部 Levi 氏液国定，PAS- 鉄ヘマトキシリン染色 $(10 \times 90)$ 上と同様であるが，乙こでは染色性の低下した原形質性分必突起をしばしばみる（个）.

w．連続非発情せるラット子宮 Levi 氏液固定，PAS-鉄へマトキシリン染色 $(10 \times 10)$ 上皮はかなり低く， 腔は狭小で平坦である.

X，連続非発情せるラツト子宮粘膜上皮細胞 Levi 氏液固定，PAS-鉄ヘマトキシリン染色 $(10 \times 90)$ 上皮細 胞内に多数の脂肪顆粒が見られる。 

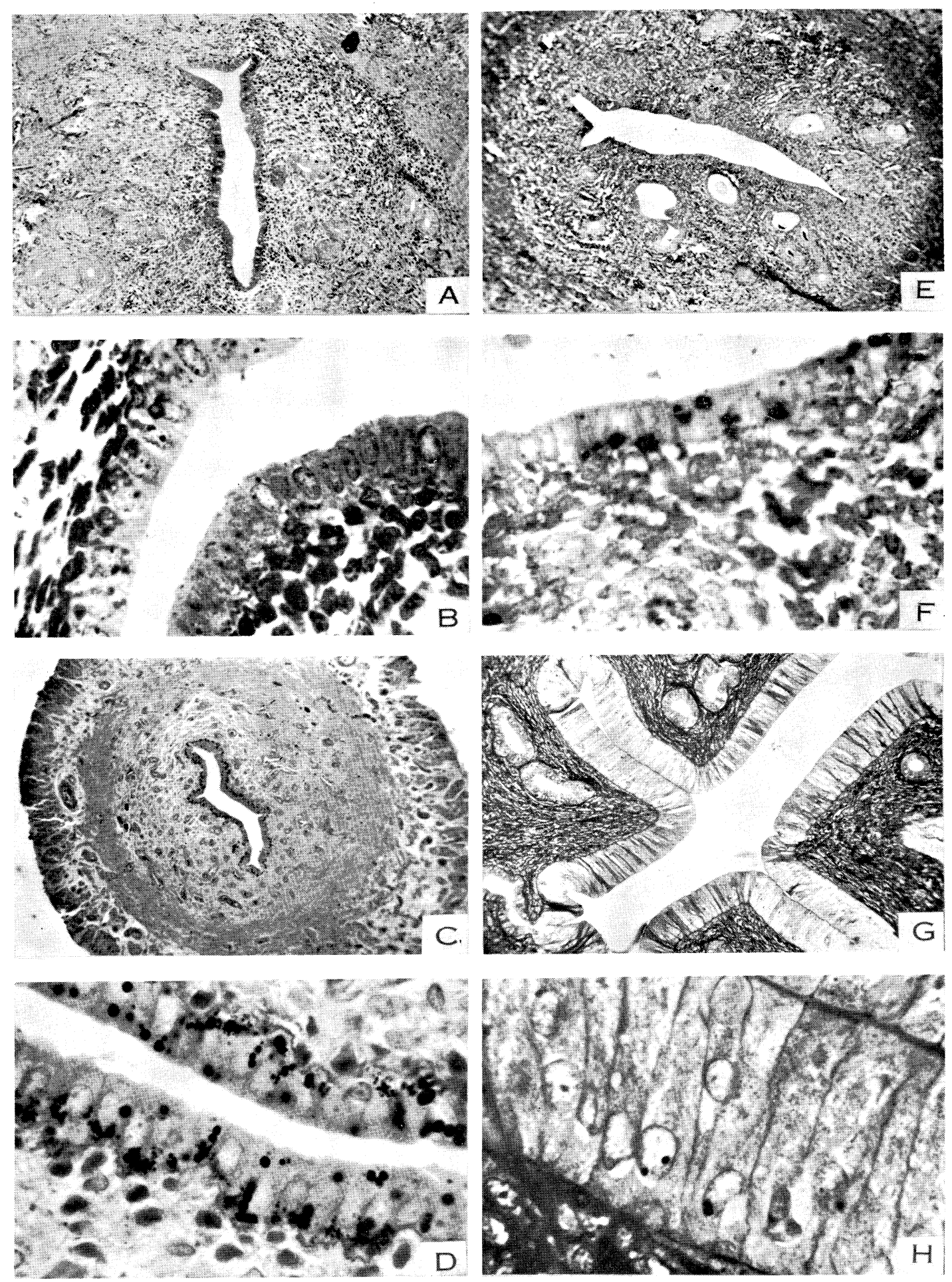
飯島論文附威（その 2 ）
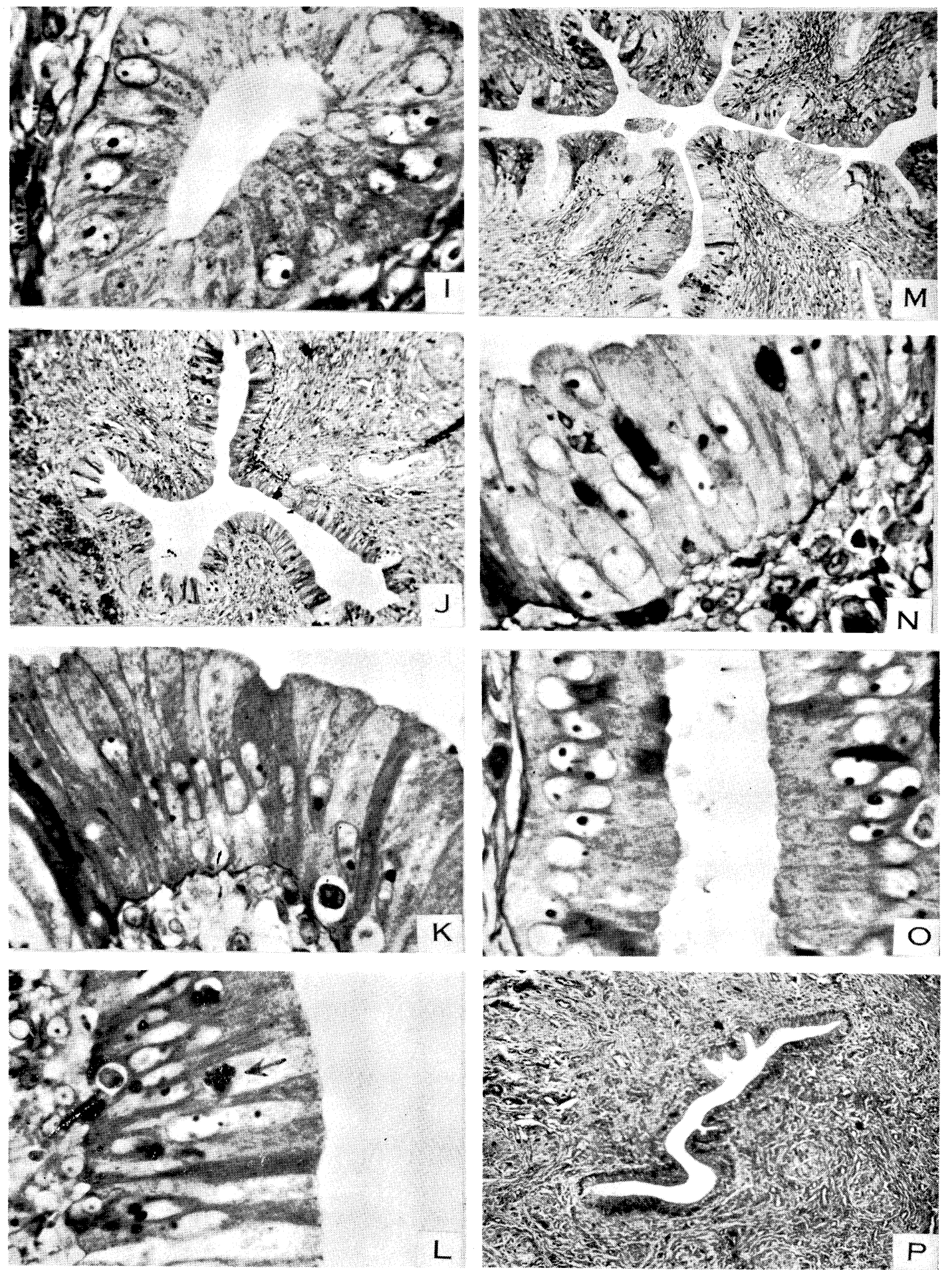


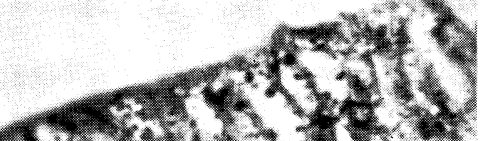

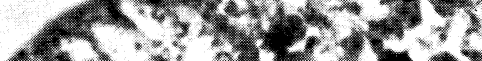

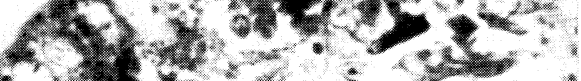

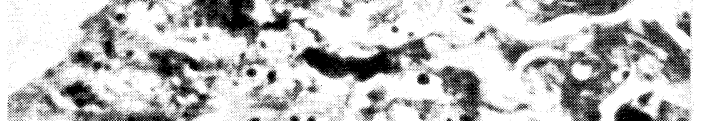

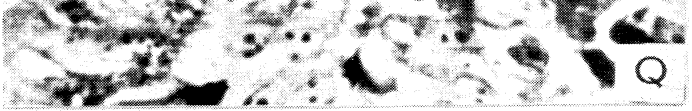
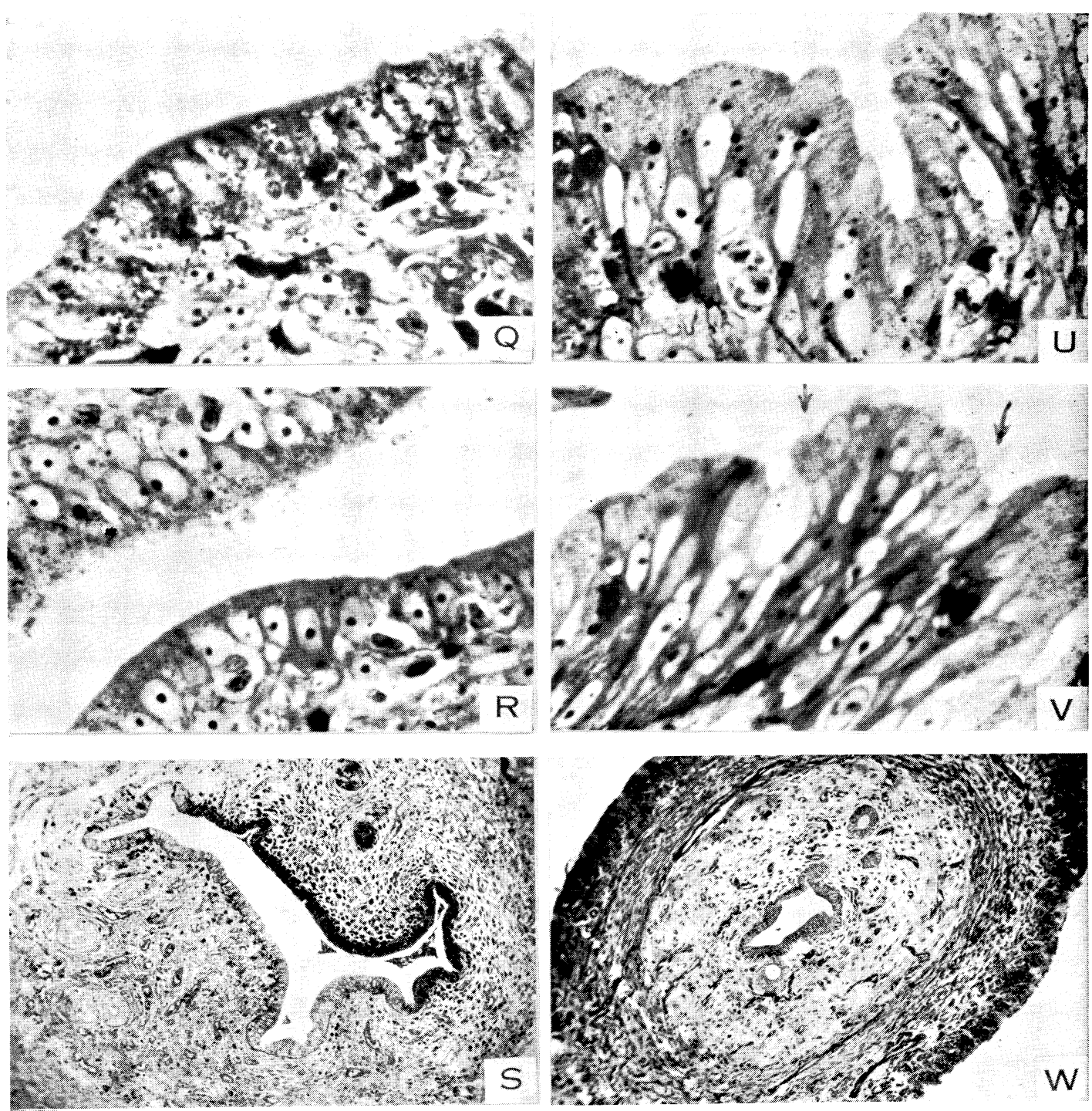

ह

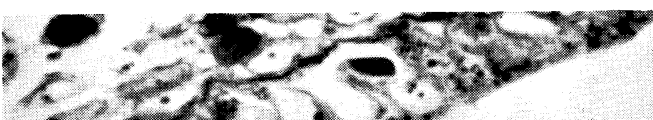

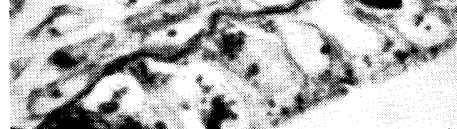
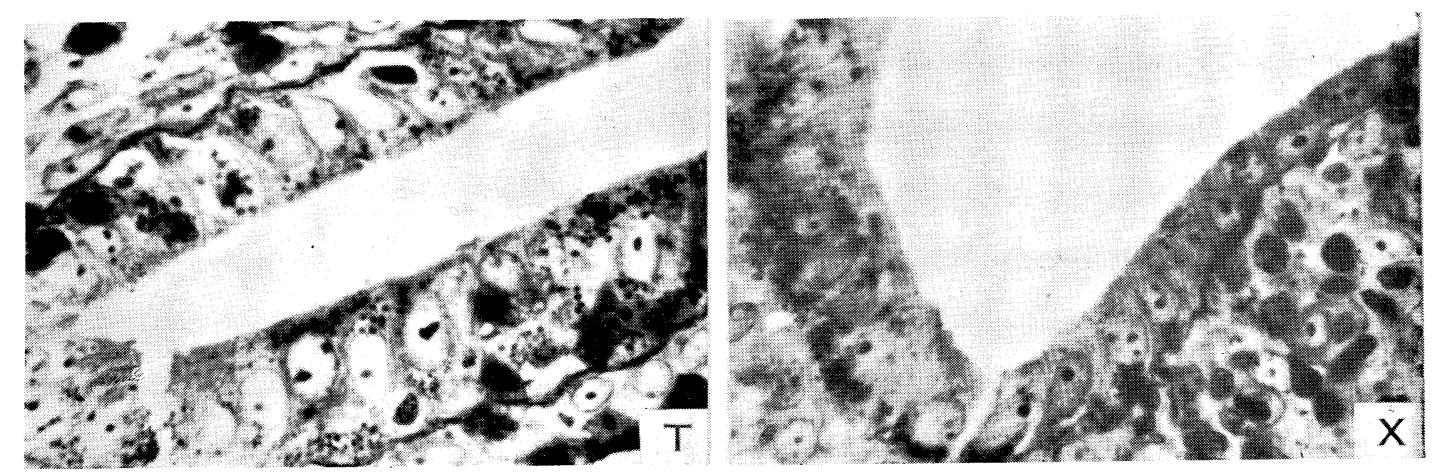